\title{
Detection of Coxiella burnetii (Query Fever) DNA by Nested-PCR in Beef Cattle from Ampel Slaughterhouse, Boyolali Regency, Middle Java, Indonesia
}

\author{
Eko Prasetyo Nugroho ${ }^{1}$, Agus Setiyono ${ }^{* 2}$, Upik Kesumawati Hadi ${ }^{3}$, Wiwin Winarsih ${ }^{2}$, and Dwi Astuti ${ }^{d}$ \\ ${ }^{I}$ Graduate School, Animal Biomedical Science Study Program, Faculty of Veterinary Medicine, Bogor Agricultural University (IPB University), Bogor, Indonesia \\ ${ }^{2}$ Division of Veterinary Pathology, Faculty of Veterinary Medicine, Bogor Agricultural University (IPB University), Bogor, Indonesia \\ ${ }^{3}$ Division of Veterinary Parasitology and Entomology, Faculty of Veterinary Medicine, Bogor Agricultural University (IPB University), Bogor, Indonesia \\ ${ }^{4}$ Biology Research Center, Division of Zoology, Indonesian Institute of Sciences, Bogor, Indonesia \\ *Corresponding author's Email: agusse@apps.ipb.ac.id; (D) ORCiD: 0000-0001-7023-6420
}

\begin{abstract}
Coxiella burnetii $($ C. burnetii) is a Gram-negative and obligate intracellular bacterium that causes Query fever $(\mathrm{Q}$ fever). The aim of the present study was to detect $C$. burnetii in beef cattle from Ampel slaughterhouse at Boyolali Regency, Middle Java, Indonesia. Spleen, heart, liver, lung, and kidney samples were collected from 100 cattle and used for Nested-PCR (nPCR) with four types of primers (OMP1, OMP2, OMP3, and OMP4). Five stages of pooling extraction were performed on 100 individual samples. The nPCR amplified a 437 bp DNA fragment from the fifth pool on the sampled heart, lung, and spleen. Furthermore, 10 individual samples from the fifth pool were re-tested by nPCR to find out the number of positive individual samples. Of 10 samples, the obtained result indicated the presence of $C$. burnetii DNA in 7 samples, 6 from Simmental cattle and 1 from Ongole cattle. Therefore, it can be strongly suspected that there are 7 out of 100 local breed beef cattle positive of Q fever at Boyolali Regency, Middle Java, Indonesia.
\end{abstract}

Keywords: Beef cattle, Boyolali, Coxiella burnetii, Nested-PCR, Query fever case.

\section{INTRODUCTION}

Coxiella burnetii (C. burnetii) is a Gram-negative and obligate intracellular bacterium that causes Query fever which is also known as coxiellosis. This disease is highly contagious and zoonotic (OIE, 2010; Eldin et al., 2017), and can be transmitted through aerosol and direct contact with infected animals or objects that are contaminated with the agent (Ergas et al., 2006). Flies (Stomoxys sp., Musca sp.) and ticks (Ixodidae, Argasidae) are ectoparasites that act as vectors causing the transmission of Q fever agent among animals, both from domestic to wild animals and also domestic to other domestic animals (Maurin and Raoult, 1999; Eldin et al., 2017). Livestock that can be infected are ruminants such as cattle, sheep, and goats, wild animals, pets, and even poultry.

Coxiella burnetii infection is often poorly symptomatic in animals. Symptoms that appear include decreased appetite, respiratory disorders, and reproductive disorders, such as abortion (Fournier et al., 1998). In humans, $C$. burnetii infection can be acute or chronic. The main clinical forms of acute $\mathrm{Q}$ fever in humans are pneumonia, hepatitis, and flu-like syndrome, while chronic $\mathrm{Q}$ fever causes poor conditions, including endocarditis, vascular, and chronic infections in pregnant women (Lodrigue et al., 2006; CDC, 2019). Chronic Q fever develops months or years following initial Q fever infection. Stein et al. (2005) showed that aerosol transmission of Q fever causes severe lesions in the lung.

Query fever is present in many countries around the world, such as the USA, Canada, Australia, and several countries in Africa and Asia (OIE, 2017). As a contagious disease, Q fever is the most neglected zoonosis in Indonesia. Compared to other diseases, such as rabies, anthrax, and salmonellosis, this disease has received less public attention. Considering the conducted studies on $\mathrm{Q}$ fever in Indonesia, Brahman Cross (BX) cattle were the main source of $C$. burnetii. In fact, Q fever cases in Indonesia were reported in BX cattle (Setiyono, 2014), Balinese cattle (Mahatmi et al., 2007), sheep, and goat (Mahatmi et al., 2007; Setiyono et al., 2008). Moreover, Q fever cases have already spreads to some regions in Indonesia, such as Bogor (Mahatmi et al., 2007; Setiyono et al., 2008), Depok (Rini et al., 2019), Jakarta (Setiyono et al., 2008), Malang (Mahatmi et al., 2007), Bali (Mahatmi et al., 2007) and Medan (Nasution et al., 2015). So far, the incidence of the disease in Boyolali Regency has not been reported and the current study was the first case of $\mathrm{Q}$ fever in beef cattle at Boyolali Regency, Middle Java, Indonesia. With this in mind, the present study aimed to detect C. burnetii in beef cattle at Boyolali Regency, Middle Java, Indonesia. 


\section{MATERIALS AND METHODS}

\section{Sampling}

The samples included heart, liver, lung, spleen, and kidney organs from 100 cattle collected by pooling technique (Rini et al., 2019). Each type of extracted organ was put in a different tube at every stage of the pooling extraction. To enhance efficiency and reduce non-specific PCR product, only the heart organ was used for the individual test which was based on pooling tests, showing the brightest band. The organ samples were collected by purposive random sampling (Rini et al., 2019) from local beef cattle, such as Simmental, Ongole, Fresian Holstein, and Brahman breeds slaughtered at the Ampel Slaughterhouse, Boyolali Regency, Middle Java, Indonesia from 19 to 21 June 2017.

Each organ was trimmed into cubes $(3 \mathrm{~cm}$ thick), wrapped in aluminum foil, placed in a plastic container, and stored in a coolbox to maintain the cold chain and freshness of the organ. Until the last day, the collected organs were temporarily stored in the freezer $\left(-30^{\circ} \mathrm{C}\right)$ at the Laboratory of Balai Pelayanan Kesehatan Masyarakat Veteriner (Bapel Kesmavet) Boyolali Regency. The organs were placed in a coolbox with an icepack and transported by car to be tested at the Integrated Laboratory, Faculty of Veterinary Medicine, Bogor Agricultural University (IPB University), Bogor, Indonesia.

\section{Nested- polymerase chain reaction}

DNA extraction was carried out according to the method introduced by Ho et al. (1995) using DNA Purification Kit; Solid tissue protocol (Gentra ${ }^{\circledR}$ Puregene ${ }^{\circledR}$, Qiagen, Germany). Frozen fresh tissue of each organ was cut into 3-5 $\mathrm{mg}$ pieces and grounded for the extraction. Initial screening used pooling techniques on 100 cattle samples in 5 stages. All organs (heart, liver, lung, spleen, and kidney) were extracted and placed on different tubes so there were five tubes of pooling sample organs in every stage. In the first and third pool stage, 25 samples were extracted, respectively. In the second and the fourth pool stage, every 20 samples were extracted while in the fifth pool stage as many as 10 samples were extracted. After initial screening, 10 individual samples from the fifth pool were re-tested to see which cattle were positive for $\mathrm{Q}$ fever.

The DNA amplification was performed by Nested-PCR (nPCR). The DNA sample was amplified on a thermal cycler machine (GeneAmp PCR systems 9600, Perkin-Elmer®, USA). The first-round PCR was programmed for 35 cycles. There were pre-denaturation $\left(94^{\circ} \mathrm{C}, 3\right.$ minutes), denaturation $\left(94^{\circ} \mathrm{C}, 1\right.$ minute), annealing $\left(54^{\circ} \mathrm{C}, 1\right.$ minute), extension $\left(72^{\circ} \mathrm{C}, 2\right.$ minutes), final extension $\left(72^{\circ} \mathrm{C}, 4\right.$ minutes), and cooling $\left(4^{\circ} \mathrm{C}, \infty\right)$. The first-round PCR product was 501 bp (OMP1 and OMP2, Ogawa et al., 2004). The primers used in the PCR test are shown in Table 1.

DNA amplification in nPCR was programmed for 35 cycles. It started with pre-denaturation $\left(94^{\circ} \mathrm{C}, 3\right.$ minutes), denaturation $\left(94^{\circ} \mathrm{C}, 1\right.$ minute), annealing $\left(56^{\circ} \mathrm{C}, 1\right.$ minute), extension $\left(72^{\circ} \mathrm{C}, 1\right.$ minute and 30 seconds), final extension $\left(72^{\circ} \mathrm{C}, 4\right.$ minutes), and cooling $\left(4^{\circ} \mathrm{C}, \infty\right)$. The nested-PCR product was a DNA amplicon of $437 \mathrm{bp}(\mathrm{OMP} 3$ and OMP4, Ogawa et al., 2004).

Table 1. Sequences of oligonucleotides used as primers for first-round and Nested-PCR

\begin{tabular}{|c|c|c|c|}
\hline PCR & Primer & Sequence & Base Pair \\
\hline \multirow{2}{*}{ First Round } & OMP1 & $5^{\circ}-$ AGT AGA AGC ATC CCA AGC ATT- 3 & \multirow{2}{*}{$501 \mathrm{bp}$} \\
\hline & OMP2 & 5'- TGC CTG CTA GCT GTA ACG ATT- 3' & \\
\hline \multirow{2}{*}{ Nested } & OMP3 & $5^{6}$-GAA GCG CAA CAA GAA GAA CAC-3' & \multirow{2}{*}{$437 \mathrm{bp}$} \\
\hline & OMP4 & $5^{\circ}$-TTG GAA GTT ATC ACG CAG TTG-3 ‘ & \\
\hline
\end{tabular}

Reference: Ogawa et al. (2004)

\section{Electrophoresis}

After the amplification process on the PCR machine was completed, electrophoresis was carried out to see the amplification results using electrophoresis gel (Agarose Gel Electrophoresis, Takara ${ }^{\circledR}$, Japan) (Ogawa et al., 2004). Electrophoresis reading was visualized as DNA fragments in bands. The result of visualization of electrophoresis was viewed under UV luminescence and then it was photographed.

\section{RESULTS AND DISCUSSION}

On the first-round PCR, samples did not indicate any band neither pooling (Figure 1A) nor individual sample (Figure 1B). On nPCR, there were three organ pools (Figure 2) with positive Q fever, including samples of heart, lung, and spleen from the fifth pool (Table 2). After the 10 individual samples were re-tested from the fifth pool, it was found that there were 7 out of 10 positive samples of Q fever (Figure 3). The heart organ was only used for an individual test because based on pooling tests, these organ pools showed the brightest band. As Hermansyah et al. (2018) explained, good DNA quality has a high DNA concentration and it is also characterized by the high intensity of the produced DNA bands. 
Table 2. Result of nPCR of five stages organ pool extraction

\begin{tabular}{|c|c|c|c|c|c|}
\hline \multirow{2}{*}{ Pooling Stages } & \multicolumn{5}{|c|}{ Organs } \\
\hline & Heart & Spleen & Lung & Liver & Kidney \\
\hline 1 & - & - & - & - & - \\
\hline 2 & - & - & - & - & - \\
\hline 3 & - & - & - & - & - \\
\hline 4 & - & - & - & - & - \\
\hline 5 & + & + & + & - & - \\
\hline
\end{tabular}
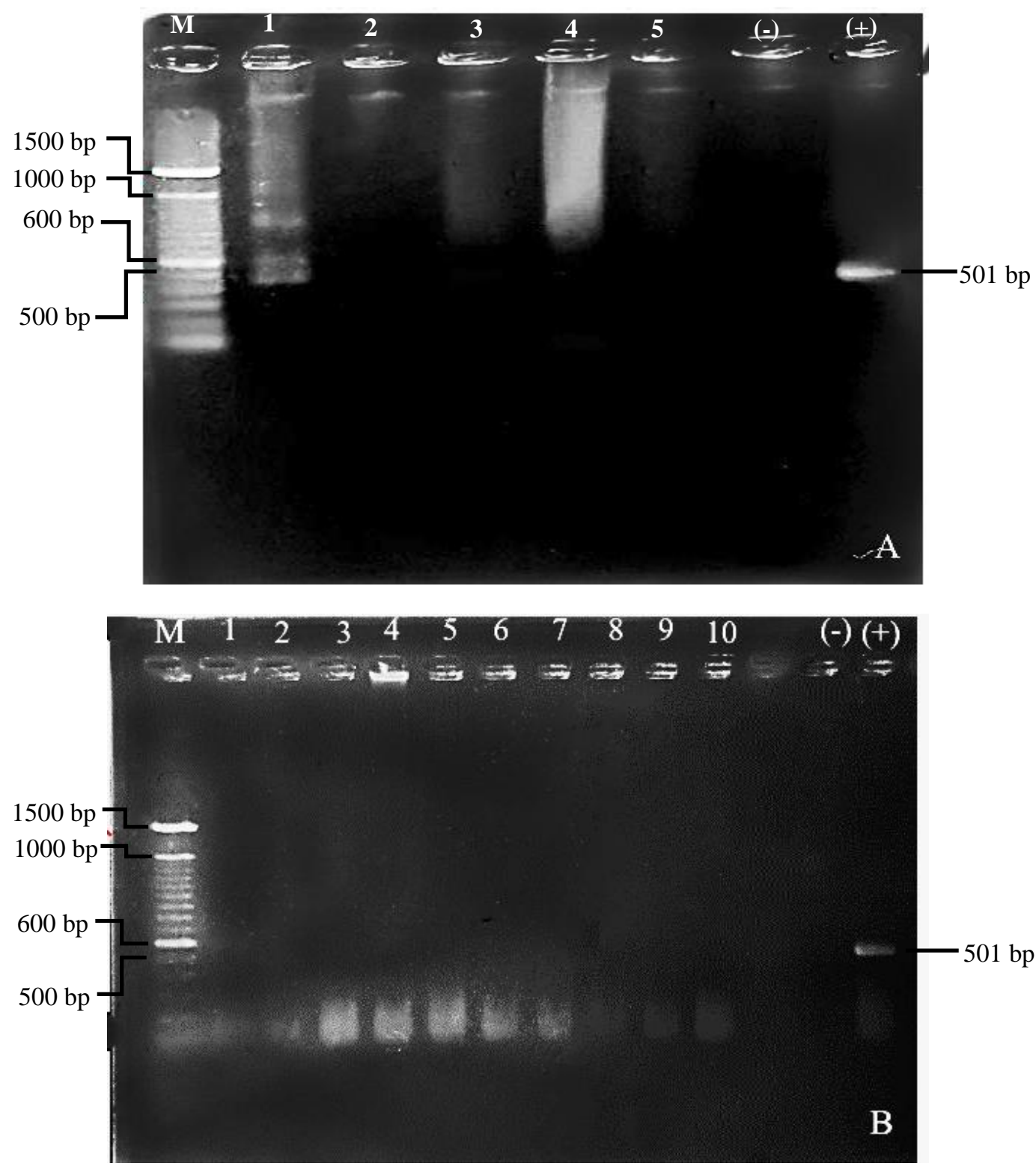

Figure 1. The result of first-round PCR result from the fifth pool (A). 1: Heart, 2: Lung, 3: Spleen, 4: Liver, 5: Kidney and individual extraction; B: 1-10: Individual sample. M: Marker, +: Positive control, C. burnetii strain Nine Mile, -: Negative control/ aquabidest

Both the pooling and the individual sample on the first round PCR did not show a fluorescent band at $501 \mathrm{bp}$ (Figure 1). At line 1 on the pooling test (Figure 1A), the fragment wasnot formed at $501 \mathrm{bp}$ (non-specific band) because PCR only used PCR products from external primers (OMP1 and OMP2) that possibly formed a non-specific band. Meanwhile, nPCR used a first-round PCR product that was re-amplified using internal primers (OMP3 and OMP4) so $C$. burnetii DNA could be detected even at low concentrations (Purnawarman et al., 2012). According to Purnawarman et al. (2012), nPCR is adequate to detect the presence of $C$. burnetii DNA with concentrations less than 300 pg, while PCR can only detect the presence of these antigens at concentrations less than $15 \mathrm{ng}$. Therefore, products from the animal origin containing $C$. burnetii DNA with concentrations less than 300 pg (nPCR) or less than 15 ng (PCR) could not be detected. The use of two pairs of primers (OMP1-OMP2 and OMP3-OMP4) is 50 times more sensitive than one pair of primers (OMP1-OMP2) (Purnawarman et al., 2012). The use of the OMP primer set (OMP1, OMP2, OMP3, and OMP4) has been used by Ho et al. (1995) and Ogawa et al. (2004) as well as other studies for highly conserved amplification of 
the outer layer protein of $C$. burnetii. Zhang et al. (1998) explained that these two pairs of oligonucleotide primers were designed to amplify a $437 \mathrm{bp}$ fragment of the coml gene encoding a 27-kDa outer membrane protein of $C$. burnetii that highly conserved among 21 strains of $C$. burnetii.

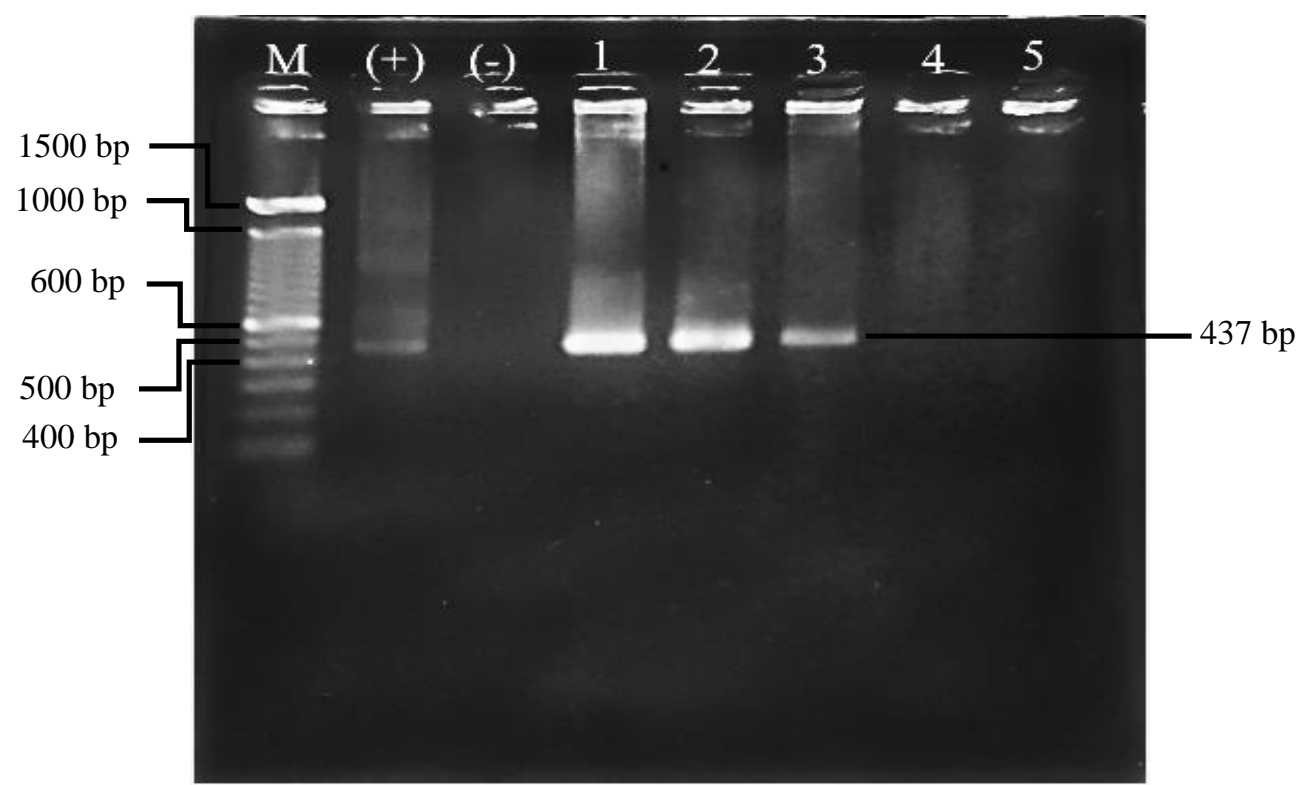

Figure 2. The result of electrophoresis of nPCR from the fifth pool. M: Marker; + : Positive control, C. burnetii strain Nine Mile; - : Negative control/ aquabidest; 1: Heart; 2: Lung; 3: Spleen; 4: Liver; 5: Kidney

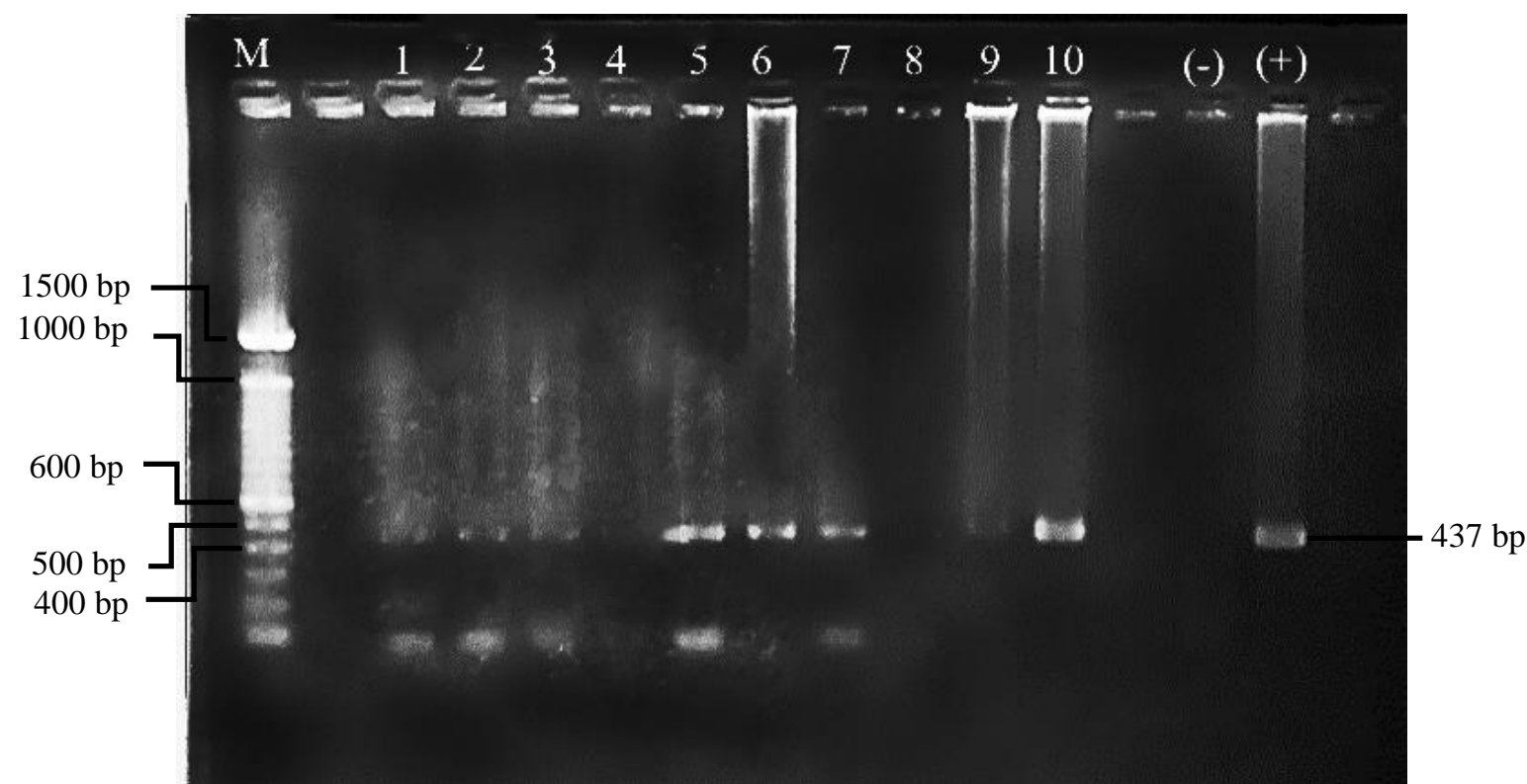

Figure 3. The result of electrophoresis of nPCR from individual extraction (heart organ). M: Marker; +: Positive control, C. burnetii strain Nine Mile; -: Negative control/ aquabidest; 1-10: Individual sample

The wide distribution of Coxiellosis around the world has lead to serious health problems both in humans and animals. Query fever, for instance, is highly contagious and can be categorized as a zoonotic emerging infectious disease (CFSPH, 2007; OIE, 2010). Query fever transmission can occur through direct contact with infected animals or contaminated dust particles, and also via vectors (as a vector-borne disease, Setiyono, 2005; CFSPH, 2007). In 2005, Indonesia imported 350,000 cattle from America and nearly 500,000 cattle from Australia (Ariningsih, 2014), where there are still instances of Q fever. Several studies in Indonesia showed that BX cattle found in Indonesia were positive for Q fever (Setiyono, 2005). Research on Balinese and BX cattle indicated $6.12 \%$ positive C. burnetii DNA using the nested PCR method in Bali and Bogor (Mahatmi et al., 2007). The result of immunohistochemical examination showed that $62 / 162(38.3 \%)$ samples of BX cattle which were collected from slaughterhouses of Medan City and Deli Serdang Regency were immunoreactive against C. burnetii (Nasution et al., 2015).

A total of seven samples were found positively infected with $C$. burnetii. Six out of seven samples were from Simmental cattle and one sample was from Ongole cattle. Based on these results, local breed beef cattle at Boyolali Regency were reported positively infected with Q fever. Beef cattle slaughtered in Ampel slaughterhouse were positively infected with $C$. burnetii using PCR examination (Table 2). The results provoke more expectations about Q fever 
infection in the cattle of other regions in Indonesia. The local breed cattle dominantly raised (Simmental and Ongole) in Boyolali Regency were positive for Q fever, presumably due to the transmission from BX cattle of Bandung which were slaughtered at Ampel slaughterhouse. Contact between BX cattle and local breed cattle may occur during travel or at the shelters. Mahatmi et al. (2007) reported that there were $3(4.29 \%)$ positive Balinese cattle that were infected with $C$. burnetii in Bali. Nugroho et al. (2021) also mentioned that beef cattle in Boyolali Regency were positive for Q fever based on immunohistochemical examinations.

Clinical signs in animals are poorly symptomatic and often characterized by decreased appetite, respiratory distress, and reproductive disorders (Lodrigue et al., 2006). Query fever in ruminants causes abortion in the last third trimester of gestation and other reproduction disorders, such as metritis (Honarmand, 2012; Eldin et al., 2017), leading to economical problems for the breeders. Coxiella burnetii can survive for several years in the host without any symptoms. It may be still excreted by animals with subclinical Q fever. There are still many Indonesian people who do not fully understand this disease and society often underestimates the symptoms caused by this disease. This is a particular concern to individuals who come into direct contact with livestock, such as veterinarians, breeders, or slaughterhouse workers, who are at the risk of becoming infected with this disease. The main infection route from animal to human is airborne (Maurin and Raoult, 1999). There are some signs of this disease in humans, such as flu-like symptoms, pneumonia, hepatitis, and nephritis (Maurin and Raoult, 1999; Honarmand, 2012). These signs respond differently to each individual from mild to severe. However, most acute signs are self-limiting but can develop to chronic and cause endocarditis. The mortality rate for Q fever in humans can vary from low to high (Honarmand, 2012; Eldin et al., 2017).

Infection widely spreads through almost all over the body organs, including the lung, heart, and spleen which indicates a systemic infection (Table 2). Lung infection is related to acute Q fever because this organ acts as the early site of the infection. This agent is distributed to the circulation system leading to a heart infection. The spleen is the most important organ on the lymphatic system so that systemic infection of $C$. burnetii causes infection to the spleen. Liver and kidney were negative for $C$. burnetii DNA based on the nPCR test because the infection was not in the chronic stage.

\section{CONCLUSION}

Although Query fever ( $Q$ fever) as a zoonotic disease is still neglected in Indonesia, it is of utmost importance to detect this disease in Indonesia due to its detrimental effects on both livestock and humans. The obtained results of the present study revealed that the incidence of $\mathrm{Q}$ fever has occurred in local beef cattle in Boyolali Regency, Middle Java, Indonesia. It can be strongly suspected that there were 7 out of 100 local breed beef cattle positive of Q fever at Boyolali Regency, Middle Java, Indonesia. Further studies are needed to obtain local isolates of $C$. burnetii so that the mapping of $\mathrm{Q}$ fever in Indonesia can be carried out optimally.

\section{DECLARATION}

\section{Acknowledgment}

The present study was one part of the projects funded and sponsored by the Indonesian Ministry of Education and Culture (formerly known as The Indonesian Ministry of Research and Higher Education).

\section{Ethical approval}

In the current study, no ethical approval was required. The procedures were non-invasive and did not involve living animals. The samples included organs of cattle that were slaughtered at the Ampel Slaughterhouse. Slaughter was carried out by a certified butcher under the supervision of an official veterinarian.

\section{Competing interests}

All the authors declare no competing financial or personal interest

\section{Authors' contribution}

Eko Prasetyo Nugroho, Prof. Agus Setiyono, Prof. Upik Kesumawati Hadi, Dr. Wiwin Winarsih, and Dr. Dwi Astuti were the authors who have contributed to the preparation of this paper. Prof Agus Setiyono was the head of the research team who has been researching zoonotic Q fever for a long time. He was responsible for the ongoing research from the beginning until this paper can be made. Eko Prasetyo Nugroho conceptualized research ideas and implemented all laboratory activities. Prof. Upik Kesumawati Hadi, Dr. Wiwin Winarsih, and Dr. Dwi Astuti were members of the supervisory committee who provided many inputs on optimizing research methods and writing this paper. All the authors read and approved the final paper manuscript.

\section{Ethical considerations}

Ethical issues (including plagiarism, consent to publish, misconduct, data fabrication and/or falsification, double publication and/or submission, and redundancy) have been checked by the authors before the submission. 


\section{REFERENCES}

Centers for Disease Control and Prevention (CDC) (2019). Q fever. Georgia USA : National Center for Infectious Diseases, Division of Viral and Rickettsial Diseases, Viral and Rickettsial Zoonoses Branch, Atlanta. Available at: https://www.cdc.gov/qfever/index.html

Center for Food Security and Public Health (CFSPH) (2007). Q fever. Ames Iowa (US): Iowa State University College of Veterinary Medicine, pp. 1-6. Available at: https://www.cfsph.iastate.edu/Factsheets/pdfs/q_fever.pdf

Ariningsih E (2014). Performance of national beef self-sufficiency policy. Forum Penelitian Agro Ekonomi, 32(2): 137-156. DOI: http://www.doi.org/10.21082/fae.v32n2.2014.137-156

Eldin C, Melenotte C, Mediannikov O, Ghigo E, Million M, Edouard S, Mege JL, Maurin M, and Raoult D (2017). From Q fever to Coxiella burnetii infection: A paragigm change. Clinical Microbiology Review, American Society for Microbiology, 30(1): 116190. DOI: http://www.doi.org/10.1128/CMR.00045-16

Ergas D, Keysari A, Edelstein V, and Sthoeger ZM (2006). Acute Q fever in Israel: Clinical and laboratory study of 100 hospitalized patients. Israel Medical Association Journal, 8: 337-341. Available at: https://pubmed.ncbi.nlm.nih.gov/16805234/

Fournier PE, Thomas JM, and Raoult D (1998). Minireview: Diagnosis of Q fever. Journal of Clinical Microbiology, 36(7): 18231834. DOI: http://www.doi.org/10.1128/JCM.36.7.1823-1834.1998

Hermansyah H, Sutami N, and Miksusanti (2018). Amplifikasi PCR domain D1/D2 28S rDNA menggunakan primer ITS1 dan ITS4 sampel DNA dari Candida tropicalis yang diisolasi dengan metode pendinginan. Indonesian Journal of Pure and Applied Chemisty, 1(1): 1-9. DOI: http://www.doi.org/10.26418/indonesian.v1i1.26037

Ho T, Htwe KK, Yamasaki N, Zhang GQ, Ogawa M, Yamaguchi T, Fukushi H, and Hirai K (1995). Isolation of Coxiella burnetii from dairy cattle and ticks, and some characteristics of the isolates in Japan. Microbiology and Immunology, 39(9): 663-671. DOI: http://www.doi.org/10.1111/j.1348-0421.1995.tb03254.x

Honarmand H (2012). Q fever: An old but still a poorly understood disease. Hindawi publishing corporation, Interdisciplinary Perspectives on Infectious Disease, 4: 1-8. DOI: http://www.doi.org/10.1155/2012/131932

Lodrigue KER, Zhang GQ, McMurry DN, and Samuel JE (2006). Clinical and pathological change in a guinea pig aerosol challenge model of acute Q fever. Infection and Immunity, 6: 6085-6091. DOI: http://www.doi.org/10.1128/IAI.00763-06

Mahatmi H, Setiyono A, Damayanti RS, and Pasaribu FH (2007). Deteksi Coxiella burnetii penyebab Q fever pada sapi, domba dan kambing di Bogor dan Bali. Jurnal Veteriner, 8(4): 180-187. Available at: https://ojs.unud.ac.id/index.php/jvet/article/view/3213

Maurin M, and Raoult D (1999). Q fever. Clinical Microbiology Reviews, 12(4): 518-533. DOI: http://www.doi.org/10.1128/CMR.12.4.518

Nasution SS, Setiyono A, and Handharyani E (2015). Deteksi imunohistokimia antigen Coxiella burnetii sebagai penyebab Q fever pada sapi. Jurnal Kedokteran Hewan, 9(2): 147-151. DOI: http://www.doi.org/10.21157/j.ked.hewan.v9i2.2835

Nugroho EP, Setiyono A, Hadi UK, Winarsih W, and Astuti D (2021). Immunohistochemical detection of Coxiella burnetii in cattle spleen organ from Ampel Slaughterhouse, Boyolali Regency. Jurnal Medik Veteriner, 4(1): 1-8. DOI: http://www.doi.org/10.20473/jmv.vol4.iss1.2021.48-55

Office International des Epizootics (OIE) (2010). Q fever. Available at: https://www.oie.int/fileadmin/Home/eng/Health_standards/tahm/3.01.16_Q_FEVER.pdf

Office International des Epizootics (OIE) (2017). Q fever. Available at: https://www.oie.int/en/disease/q-fever/

Ogawa M, Setiyono A, Sato K, Cai Y, Shiga S, and Kishimoto T (2004). Evaluation of PCR assays currently used for detection of Coxiella burnetii in Japan. The Southeast Asian Journal Tropical Medicine and Public Health, 35(4): 151-154. Available at: https://www.tm.mahidol.ac.th/seameo/2004_35_4/14-3322.pdf

Purnawarman T, Wibawan IWT, Pasaribu FH, Setiyono A, and Saepulloh M (2012). Sensitivitas dan Spesifisitas Nested Polymerase Chain Reaction untuk mendeteksi DNA Coxiella burnetii. Jurnal Veteriner, 13(1): 51-56. Available at: https://ojs.unud.ac.id/index.php/jvet/article/view/2138

Rini EP, Setiyono A, Wibawan IWT, Juniantito V, and Astuti D (2019). Detection of Coxiella burnetii infection in various organs from beef cattle in Depok, West Java, Indonesia. Advances in Health Sciences Research, 19: 67-70. DOI: http://www.doi.org/10.2991/isessah-19.2019.19

Setiyono A (2005). Q fever ditinjau dari aspek zoonosis (review on zoonosis of Q fever). Seminar Nasional Teknologi Peternakan dan Veteriner. Bogor, Indonesia, 12-13 September. Available at: https://docplayer.info/40841270-Q-fever-ditinjau-dari-aspekzoonosis.html

Setiyono A (2014). Cellular pathogenesis of Query fever in cattle. Global Veterinaria, 13(5): 668-671. DOI: http://www.doi.org/10.5829/idosi.gv.2014.13.05.85239

Setiyono A, Handaryani E, and Mahatmi H (2008). Seroprevalensi Q fever pada domba dan kambing di wilayah Jawa Barat. Jurnal Ilmu Ternak dan Veteriner, 13(1): 61-66. Available http://download.garuda.ristekdikti.go.id/article.php?article $=460541 \&$ val $=7168 \&$ title $=$ Seroprevalence $\% 20$ of $\% 20 \mathrm{Q} \% 20 \mathrm{fever} \% 20 \mathrm{i}$ n\%20sheep\%20and\%20goat\%20in\%20West\%20Java\%20area

Stein A, Louveau C, Lepidi H, Ricci F, Baylac PB, Davoust B, and Raoult D (2005). Q fever pneumonia: Virulence of Coxiella burnetii pathovars in a murine model aerosol infection. Infection and Immunity, 73(4): 2469-2477. DOI: http://www.doi.org/10.1128/IAI.73.4.2469-2477.2005

Zhang GQ, Nguyen SV, To H, Ogawa M, Hotta A, Yamaguchi T, Kim HJ, Fukushi H, and Hirai K (1998). Clinical evaluation of a new PCR assay for detection of Coxiella burnetii in human serum samples. Journal of Clinical Microbiology, 36(1): 77-80. DOI: http://www.doi.org/10.1128/JCM.36.1.77-80.1998 